\title{
Application of the Spielberger's State-Trait Anger Expression Inventory in clinical patients
}

\author{
Flávia Barros de Azevedo', Yuan-Pang Wang 2,3, \\ Alessandra Carvalho Goulart 1,4,5, Paulo Andrade Lotufo 1,4,5, \\ Isabela Martins Benseñor ${ }^{1,4,5}$
}

\begin{abstract}
Objective: To examine the factor structure of the Portuguese version of State-Trait Anger Expression Inventory (STAXI) in clinical patients. Method: 400 subjects from an internal medicine outpatient unit and 200 from a medical ward were recruited. Patients answered questions about clinical data, the STAXI, and the Beck Depression Inventory (BDI). Raw score of the STAXI was submitted to reliability assessment and factor analysis. Results: Internal consistency using the Cronbach's alpha coefficient was of 0.84 . The STAXI significantly correlated with BDI at $r=0.352(p<0.01)$. The final solution of Principal Component Analysis identified five meaningful factors: Trait-Anger, State-Anger, Anger-Control, Anger-Out, and Anger-In. This structural model is close to the original theoretical construct of Spielberger's STAXI. Conclusion: The Portuguese version of STAXI presented an adequate factorial structure that permits the evaluation of anger dimensions among clinical patients.
\end{abstract}

Key words: anger, psychometric scale, factor analysis, clinical patient.

\section{Aplicação do inventário de expressão de raiva estado-traço de Spielberger em pacientes clínicos}

\section{RESUMO}

Objetivo: Avaliar o construto e as propriedades psicométricas da versão em português do Inventário de Expressão de Raiva Estado-Traço (STAXI) em pacientes clínicos. Método: 400 indivíduos de uma unidade ambulatorial e 200 de uma enfermaria de clínica médica foram recrutados. Foram coletadas informações sobre aspectos clínicos, o STAXI e o Inventário de Depressão de Beck (BDI). Os escores brutos do STAXI foram submetidos à análise de confiabilidade e análise fatorial. Resultados: A consistência interna pelo coeficiente alfa de Cronbach foi de 0,84. O STAXI se correlacionou significativamente com BDI $(r=0,352$; $p<0,01)$. A análise de Componentes Principais identificou cinco fatores significativos: Raivatraço, Raiva-estado, Controle-de-raiva, Raiva-para-fora e Raiva-para-dentro. Esse modelo estrutural é similar ao apresentado originalmente por Spielberger. Conclusão: A versão em português do STAXI apresenta uma estrutura fatorial adequada que permite a avaliação das dimensões da raiva em pacientes clínicos.

\section{Correspondence \\ Isabela Martins Benseñor Hospital Universitário \\ Avenida Lineu Prestes 256 05508-900 São Paulo SP- Brasil E-mail: isabensenor@hu.usp.br \\ Dr. Lotufo and Dr. Benseñor are recipients of an Award for Research from Conselho Nacional de Pesquisa (CNPq), Brasília DF, Brazil}

Received 14 September 2009 Received in final form 24 November 2009 Accepted 7 December 2009
Palavras-chave: raiva, escala psicométrica, análise fatorial, pacientes clínicos.
Anger is defined as "an emotional state of feeling that varies in intensity, from mild irritation to fury and rage" ${ }^{\prime 1}$. The predisposition for frequent, intense, long-last- ing anger is a relatively enduring and stable personality known as trait anger. The expression of anger refers to how anger is managed, whether it is expressed outward-
'School of Medicine, University of São Paulo, São Paulo SP, Brazil; ${ }^{2}$ Department and Institute of Psychiatry, School of Medicine, University of São Paulo, São Paulo SP, Brazil; ${ }^{3}$ Department of Psychiatry, Santo Amaro School of Medicine - UNISA, São Paulo SP, Brazil; ${ }^{4}$ Emergency Department, Hospital das Clínicas, School of Medicine, University of São Paulo, São Paulo SP, Brazil; ${ }^{5}$ Internal Medicine Department, Hospital Universitário, School of Medicine, University of São Paulo, São Paulo SP, Brazil. 
ly, held in, or controlled ${ }^{2}$. It has been described that expressed anger is associated to increased risks of depressive symptoms ${ }^{3,4}$ and violent behavior ${ }^{5}$. Expression of anger is also related with disruptive interpersonal consequences and physical illnesses as high blood pressure ${ }^{6,7}$, coronary heart disease ${ }^{8}$ and cancer?

Previous studies evaluated anger based on the behavioral observation, clinical interviews, and self-reporting scales. Some popular tools as Cook-Medley Hostility Scale ${ }^{2}$, Buss-Durkee Hostility Inventory ${ }^{10}$, and the Anger Attacks Questionnaire ${ }^{11}$ have received criticism due to poor discrimination ability for the constructs of anger, hostility and aggression. In addition, some scales on anger have been built without explicit definition of anger persisting doubts about what is actually being measured. An important advancement in the assessment of anger was proposed by Spielberger's State-Trait Anger Expression Inventory $(\mathrm{STAXI})^{12}$. This psychometric tool evaluates anger isolated from hostility and aggression, covering the anger's experience and expression.

The aim of the present study was to examine the factor structure and psychometric properties of the Portuguese version of State-Trait Anger Expression Inventory in clinical patients recruited from a Brazilian tertiary hospital.

\section{METHOD}

This is a cross-sectional study carried out at a tertiary care facility. Six hundred adult were recruited from consecutive admissions of the internal medicine outpatient unit $(n=400)$ and the clinical ward $(n=200)$. All participants were free of prior dementia and/or psychiatric disorders that might preclude participation at study entry. The sample was comprised of 340 males (56.7\%) and 260 females (43.3\%), with mean age of 51.2 years. One-third of participants reported more than 8 years of formal education. The proportions of diagnosis were: cardiovascular (40\%), endocrine (28\%), rheumatic (13\%), infectious (7\%), respiratory (5\%), neurological (5\%), and gastrointestinal diseases (4\%). Cardiovascular diseases were more frequent among men than women ( $63 \%$ vs. $37 \%, \mathrm{p}=0.04$ ) as well as the percentage of hospitalized disabled men compared to women (69.5 vs. $30.5 \%, \mathrm{p}<0.0001)$. No other significant gender differences were observed in the sample.

We used the Portuguese version of State-Trait Anger Expression Inventory, originally translated and adapted in Brazil by Biaggio ${ }^{13}$. The STAXI provides a self-reported measure of the experience and expression of anger in 44 items. Individuals answered on a 4-point Likert scale (score range: 0-132) to assess either the intensity of their angry feelings or the frequency in which anger is experienced, expressed, or controlled. Beck Depression Inventory (BDI), was applied to all respondents concurrently with the STAXI ${ }^{14}$. It comprises 21 items to rate the intensity of depressive manifestations in a 4-point scale. Medical illnesses were assessed by staff doctors and the patients were interviewed by trained medical students. The Internal Review Board approved the study and all subjects who agreed to participate signed the informed consent.

\section{Statistical analysis}

Raw scores of the total sample and by gender were compared using ANOVA, with Bonferroni correction. The Cronbach's alpha coefficient assessed internal consistency. We also calculated Pearson's correlation between the scores of STAXI and BDI.

Sample size and strong variable correlations (KaiserMeyer-Olkin measure for sampling adequacy, $\mathrm{KMO}=0.84$, and Bartlett's test of sphericity, $\mathrm{p}<0.001$ ) were found to be suitable for factor analysis. We used Principal Component Analysis with Varimax rotation to extract the components and interpretation of the final solution. The scree plot was the factor retention criterion. Factor loading $\geq 0.4$ indicated the importance of each item to be retained in a given factor. All analyses were performed using SPSS version 13.0. Differences were taken as statistically significant for bicaudal p-values lower than 0.05 .

\section{RESULTS}

The mean STAXI score for total sample was 79.4 (SD 12.8), and there was no significant difference in scores between males (mean=80.0, SD 14.6) and females (mean=79.0, SD 13.0). Two items (\#4 "yelling at somebody" and \#8 "hitting someone") displayed differences $(\mathrm{p}<0.05)$ for the score between genders, but neither of two reached statistical significance after Bonferroni correction. Therefore, all STAXI items were considered psychometrically similar for both genders.

The Cronbach's alpha coefficient was $0.84,0.82$, and 0.87 , respectively for total sample, males and females. The item-total correlation between each item and the total score, ranged from 0.14 to 0.56 . Most of STAXI items revealed adequate correlations with the underlying construct. Some items like: 5, 7, 8, 21, 24, 31, 35, and 38, displayed lower item-total correlation $(<0.20)$, but the resulting alpha coefficients changed little after deleting these items.

Overall, the mean score of the BDI was 11.9 (SD 9.28), regardless of gender. The BDI significantly correlated with STAXI, $r=0.352(\mathrm{p}<0.01)$.

Table shows the factor structure of STAXI for the total sample. For the total sample, the five-factor solution explained $45.9 \%$ of the cumulative variance, with the first factor accounting for 17.3\% (Trait/Anger), the second factor 10.7\%, (State/Anger), the third 8.7\% (Anger/Control), the forth 5.5\% (Anger/Out), and the fifth 4.0\% (Anger/In) of the data variance. 
Table. Eigenvalue, percentage of explained variance and Cronbach's alpha coefficient for the 44 STAXI items.

\begin{tabular}{|c|c|c|c|c|c|}
\hline \multirow[b]{2}{*}{ STAXI Items } & \multicolumn{5}{|c|}{ Anger factors } \\
\hline & $\begin{array}{c}1 \\
\text { Trait Anger }\end{array}$ & $\begin{array}{c}2 \\
\text { State Anger }\end{array}$ & $\begin{array}{c}3 \\
\text { Anger Control }\end{array}$ & $\begin{array}{c}4 \\
\text { Anger Out }\end{array}$ & $\begin{array}{c}5 \\
\text { Anger In }\end{array}$ \\
\hline 14. I get angry when slowed down & 0.71 & & & & \\
\hline 18. Furious when criticized in front & 0.70 & & & & \\
\hline 20. Infuriated when poor evaluation & 0.69 & & & & \\
\hline 15. Annoyed when no recognition & 0.68 & & & & \\
\hline 11. I am quick tempered & 0.68 & & & & \\
\hline 17. When I get mad, I say nasty things & 0.66 & & & & \\
\hline 16. I fly off the handle & 0.65 & & & & \\
\hline 13. I am a hothead person & 0.60 & & & & \\
\hline 12. I have a fiery temper & 0.55 & & & & \\
\hline 19. Frustrated, feel hitting someone & 0.54 & & & & \\
\hline 6. I am mad & & 0.83 & & & \\
\hline 3. I feel angry & & 0.82 & & & \\
\hline 2. I feel irritated & & 0.72 & & & \\
\hline 10. I feel like swearing & & 0.69 & & & \\
\hline 9. I am burned up & & 0.69 & & & \\
\hline 4. I feel like yelling at somebody & & 0.68 & & & \\
\hline 1. I am furious & & 0.63 & & & \\
\hline 7. I feel like banging on the table & & 0.56 & & & \\
\hline 8. I feel like hitting someone & & $(0.36)$ & & & \\
\hline 5. I feel like breaking thing & & $(0.26)$ & & & \\
\hline 31. I control my temper & & & 0.77 & & \\
\hline 44. I control my angry feelings & & & 0.75 & & \\
\hline 35. I can stop from losing my temper & & & 0.73 & & \\
\hline 21. I control my behavior & & & 0.69 & & \\
\hline 38. I am irritated a great deal more & & & 0.66 & & \\
\hline 24. I am patient with others & & & 0.65 & & \\
\hline 40. I have to be tolerant and comprehensive & & & 0.58 & & \\
\hline 39. I say nasty things & & & & 0.64 & \\
\hline 36. I do things like slam doors & & & & 0.60 & \\
\hline 32. I argue with others & & & & 0.58 & \\
\hline 27. I make sarcastic remarks to others & & & & 0.56 & \\
\hline 22. I express my anger & & & & 0.51 & \\
\hline 43. If annoyed, apt to tell how I feel & & & 0.41 & 0.50 & \\
\hline 42. I lose my temper & & & & 0.50 & \\
\hline 34. I pout or sulk & & & & 0.47 & \\
\hline 37. Angrier than I am willing to admit & & & & 0.47 & \\
\hline 29. I do thing like slam doors & & & & 0.46 & \\
\hline 41. I argue with others & & & & 0.43 & \\
\hline 33. I tend to harbor grudges & & & & & 0.67 \\
\hline 30. Nothing force me to show anger & & & & & 0.66 \\
\hline 28. I keep frit & & & & & 0.61 \\
\hline 23. I keep things in & & & & & 0.56 \\
\hline 26. I withdraw from people & & & & & 0.54 \\
\hline 25. I become sullen & & & & & 0.43 \\
\hline Eigenvalues & 7.59 & 4.69 & 3.82 & 2.39 & 1.66 \\
\hline$\%$ of explained variance* & $17.25 \%$ & $10.67 \%$ & $8.68 \%$ & $5.45 \%$ & $3.77 \%$ \\
\hline Cronbach's alpha & 0.86 & 0.87 & 0.79 & 0.82 & 0.73 \\
\hline
\end{tabular}

Factor loadings $<0.40$ were suppressed, except for itens \#5 and \#8. *Rotated solution.

\section{DISCUSSION}

This is the first Brazilian study applying a reliable measure of anger in a clinical sample using STAXI. Although its psychometric properties had already been assessed for Brazilian college students and Navy recruits ${ }^{13}$, the pres- ent factor analysis have showed construct validity close to the Spielberger's original theoretical ground of anger psychopathology.

Previous American ${ }^{15,16}$ and Russian ${ }^{17}$ studies found that STAXI is a consistent instrument. Similarly to the 
normative study of the Brazilian sample ${ }^{13}$, the value of 0.84 for Cronbach's alpha coefficient indicated strong relationships among the items. Results of the item-total correlation revealed that all 44 items could assess homogeneously the construct of STAXI. We found no difference in scores by gender, similar to the Russian results ${ }^{17}$. However, our data was different from previous studies in American adults on Trait/Anger ${ }^{16}$ and the first Brazilian sample on Anger $/ \mathrm{In}^{13}$ that showed slightly higher values for men compared to women. In our findings some items of the State/Anger (5, 7, and 8) and Anger/ Control (21, 24, 31, 35, and 38) presented lower correlation with the total construct, but they did not affect the overall construct.

The construct covered by the BDI was significantly correlated with STAXI, suggesting a possible convergent validity of STAXI compared to BDI.

The goal of performing factor analysis is data reduction, to obtain a simple and economic structure of STAXI. Previous factor analyses had yielded slight different structures ${ }^{13,15-17}$. This could be explained by different factor extraction, retention criteria, and sample selection. The American study had extracted seven factors, but the Trait/Anger was lacking, because this dimension was included in the factor of temperament and reaction of anger $^{16}$. The Russian study have also extracted seven factors, in which the sixth and seventh factors represented Anger/ In dimension. ${ }^{16}$ Conversely, the previous Brazilian validation proposed an eight-factor solution ${ }^{13}$.

This study has some limitations. This was a cross-sectional study, in which all information was provided from participants who sought medical care in a University teaching hospital, limiting the generalization of our findings. Respondents needed assistance to answer questions due to their low educational level, what might have biased the results due to the social desirability, by minimizing or exaggerating their responses according to circumstances.
Concluding, the Portuguese version of STAXI presented an adequate factorial structure that permits the evaluation of anger dimensions among clinical patients.

ACKNOWLEDGMENTS - We gratefully acknowledge support from all the members of the Internal Medicine Department who helped for this study.

\section{REFERENCES}

1. Spielberger CD. Professional manual for the State-Trait Anger Expression Inventory. Odessa FL: Psychological Assessment resources; 1988.

2. Cook WW, Medley DM. Proposed hostility and pharisaic - virtue scales for the MMPI. J Appl Psychol 1954;38:414-441.

3. Painuly N, Sharan P, Mattoo SK. Relationship of anger and anger attacks with depression: a brief review. Eur Arch Psychiatry Clin Neurosci 2005;255:215-222.

4. Fráguas R Jr, losifescu DV, Bankier B, et al. Major depressive disorder with anger attacks and cardiovascular risk factors. Int J Psychiatry Med 2007;37:99-111.

5. Terasaki DJ, Gelaye BS, Berhane Y, Williams MA. Anger expression, violent behavior, and symptoms of depression among male college students. BMC Public Health 2009;9:13.

6. Laude D, Girard A, Consoli S, Mounirer-Vehier C, Elgohozi JL. Anger expression and cardiovascular recativity to menatl stress: a spectral analysis approach. Clini Exp Hyperten 1997;19:901-911.

7. Steele MS, Mcgarvey ST. Anger expression, age and blood pressure in modernizing Samoan adults. Psychosom Med 1997;59:632-637.

8. Siegman AW. From Type A to hostility to anger: reflections on the history of coronary prone behavior. In: Siegman AW, Smith TW (Eds). Anger, hostility and the heart. New Jersey: Lawrence Erlbaum, 1994;1-22.

9. Greer S, Morris T. Psychological attributes of women who develop breast cancer: a controlled study. J Psychosom Res1975;19:147-153.

10. Lange A, Dehghani B. Validation of the Dutch adaptation of the Buss-Durkee hostility Inventory. Behav Res Ther 1995;33:229-233.

11. Fava M, Rosenbaum JF, McCarthy M, Pava J, Steingard R, Bless E. Anger attacks in depressed outpatients and their response to fluoxetine. Psychopharmacol Bull 1991;27:275-279.

12. Spielberger CD, Krasner SS, Soloman EP. The experience, expression and control of anger. In: Janisse MP (Ed). Health psychology: individual differences and stress. New York: Springer-Verlag, 1988;89-108.

13. Spielberger CD, Biaggio A. Manual do STAXI. São Paulo SP: Vetor, 1994

14. Gorenstein C, Andrade L. Validation of a Portuguese version of the Beck Depression Inventory and State-Trait Anxiety Inventory in Brazilian subjects. Braz J Med Biol Res 1996;29:453-457.

15. Forgays DG, Forgays DK, Spielberger CD. Factor Structure of the State-Trait Anger Expression Inventory. J Pers Assess 1997;69:497-507.

16. Forgays DK, Spielberger CD, Forgays DG. Factor structure of the State-Trait Anger Expression Inventory for middle-aged men and women. Assessment 1998:5:141-155.

17. Kassinove H, Sukhodolsky DG, Eckhardt Cl, Tsytsarev SV. Development of a Russian State-Trait Anger Expression Inventory. J Clin Psychol 1997;53:543-557. 